ENTREPRENEURSHIP AND SUSTAINABILITY ISSUES

ISSN 2345-0282 (online) http://jssidoi.org/jesi/

2021 Volume 8 Number 4 (June)

http://doi.org/10.9770/jesi.2021.8.4(19)
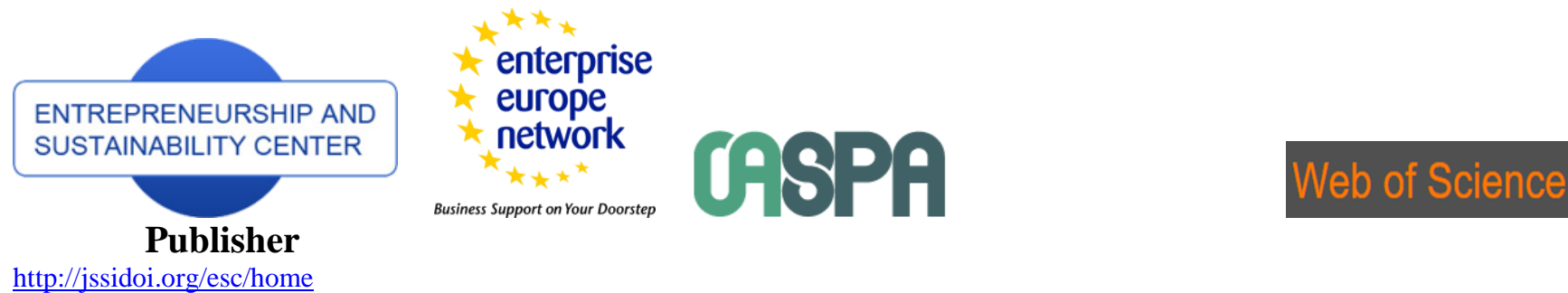

http://jssidoi.org/esc/home

Business Support on Your Doorstep PA

\title{
STRATEGIC ALIGNMENT AND IMPLEMENTATION OF CODES OF CONDUCTS IN ORGANISATIONS
}

\author{
Juliane Meixner ${ }^{1}$, Jozef Papula ${ }^{2}$ \\ ${ }^{1,2}$ Comenius University Bratislava, Faculty of Management, Odbojárov 10, 83104 Nové Mesto, Slovakia

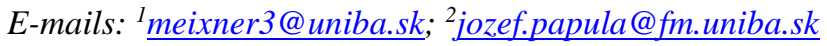

Received 10 February 2021; accepted 8 April 2021; published 30 June 2021

\begin{abstract}
Using the example of the automotive industry, this paper explores with a view to the many scandals in this particular branch (such as the Dieselgate scandal) how the values declared in the codes of conduct in this industry can be practiced in a more sustainable manner in daily business. This is because the branch has been not short on declared values, or the many strategic and operative guidelines to follow. A solution to this challenge thus likely only can be expected from a systemic approach. Based on the assumption that the level of appeal of a code is a vital but by no means sufficient prerequisite for internalisation of values, firstly indicators have been developed to assess the appeal of a code of conduct, such as the topicality of scope, comprehensiveness, relevance, comprehensibility of language and content, formal design and didactic transformation. Using these criteria, 18 codes of conduct have been analysed of companies from the automotive industry and the devised pool of criteria condensed to the key attributes that define the measure of appeal of a code. In the follow-up step, experts have been approached to give their opinions on how the values declared in the codes of conduct can be implemented in a more sustainable manner in strategic and operative alignment of corporate and management culture. This is because alongside a topical and didactically structured code of conduct, the likelihood of internalising values is higher where also the corporate organisational structure and process flows as well are adjusted for compatibility with such norms. With the aim to make the codes more effective, a total of 10 main scales and 62 criteria have been determined. Three of the scales deal with the didactic and content design of the codes, five with the organisational structure, corporate processes and controlling and two with qualifications and personal growth. The values of the variables on the scales are comprised into a summary value that represents the development level of a corporate value culture. The summary value and profiles can be used as benchmarking references and a basis for self-evaluation as well as a dynamic value management. The scales aid successful internalisation and implementation of the value culture as part of corporate culture.
\end{abstract}

Keywords: corporate social responsibility; code of conduct; ISO 26000 standard; value management; corporate culture; value controlling

Reference to this paper should be made as follows: Meixner, J., Papula, J. 2021. Strategic alignment and implementation of codes of conducts in organisations. Entrepreneurship and Sustainability Issues, 8(4), 331-348. http://doi.org/10.9770/jesi.2021.8.4(19)

JEL Classifications: M14, M59, L20 


\section{ENTREPRENEURSHIP AND SUSTAINABILITY ISSUES}

ISSN 2345-0282 (online) http://jssidoi.org/jesi/

2021 Volume 8 Number 4 (June)

http://doi.org/10.9770/jesi.2021.8.4(19)

\section{Introduction}

Values define a company's reputation and provide stability, reliability in how business relations are managed and give orientation in national and international competition (Wahyudi et al., 2020; Ji \& Ihsan 2019). As such, they reflect the efficiency of corporate operations and are a key indispensable prerequisite for market success of products and business models in a global market environment. In particular companies with a global scope of operations align their values with international standards, such as can be found in particular in the corporate social responsibility (CSR) approach (ISO 26000:2011; Grigore et al., 2020; Baumgartner, 2020). But the formal commitment to these values failed to avert major irregularities in many branches of the economy, with very public repercussions. In particular the financial crisis and the many scandals it brought around fraud and manipulation continue to raise doubts about actual real-life worth of once declared values. The result is a loss of trust not just in the banking sector (Schlick, 2019). In the meantime, many new scandals such as the Dieselgate scandal (Meck, 2017), affairs in the pharmaceutical industry (dpa \& aerzteblatt.de, 2018) due to counterfeit medicines or in the construction industry (Buschmann et al., 2018) have additionally dented trust in how effectively mandatory government supervision is actually being performed.

Against this backdrop, it is elaborated on the example of the automotive industry how despite a corporate culture that embraces ethical and social values, irregularities in conduct could occur. As part of the effort, a systemic approach is constructed that includes the variables of (a) the effects of the international value shift, (b) prerequisites in organisational structure and process flows for an implementation of values and (c) determinants that promote individual and collective internalisation of pursued values.

To promote the internalization of the intended values, the Codes of Conduct is of central importance. The degree of attractiveness and the communication of these guidelines have an effect on identification with this management instrument and thus also on the internalization of the intended values. The quality criteria that determine the degree of attractiveness of these guidelines were identified. In order to optimally influence the degree of effectiveness of the change in values, an additional process variable was used in this research approach. With this additional process variable, the three system components shown could be compatibly aligned in a coordinated dynamic process to a higher level of competence. From these considerations the thesis of this investigation approach could be confirmed: The likelihood that the values of social responsibility proclaimed and intended in the Codes of Conduct will be implemented sustainably and effectively and internalized by employees increases if identification with the Codes of Conduct is successful and the strategic and operational orientation of the corporate culture is aligned with one another, and both organizational development and individual and collective qualification are geared to the intended change in values in graduated and coordinated processes.

\section{Theoretical Background}

Synonymous with global and international alignment of values is the corporate social responsibility (CSR) approach. The approach also reflects the fast pace of change in values. The long continuity of CSR that goes back as early as the 1950s has fostered an extensive debate on sustainability and has made social responsibility a core concern in corporate policies (Bowen, 1953). While the ethical focus of CSR initially was conceived as a tentative guiding principle with self-commitment as an option, these ideas gradually evolved into social responsibility as a mandatory requirement (Ioannou \& Serafeim, 2019; Schultz, 2011). Mainly in recent years, CSR has been a growing staple in public awareness. Today, it is being increasingly discussed and recognised both nationally and internationally as a guiding principle of ethical behaviour (Camilleri 2016; Osemeke et al. 2016). By virtue of this, CSR as a concept also has been expanded ever further and has been treated increasingly as mandatory in the public debate. Many companies align their corporate culture, their codes of conduct and their sustainability reports with this particular approach (Official Journal of the European Union Directive 2014/95/EU; Federal Council 2016, printed matter: 547/16; Federal Council 2017, printed matter: 201/17). These concerns and 


\section{ENTREPRENEURSHIP AND SUSTAINABILITY ISSUES}

ISSN 2345-0282 (online) http://jssidoi.org/jesi/

2021 Volume 8 Number 4 (June)

http://doi.org/10.9770/jesi.2021.8.4(19)

intentions are addressed by the ISO 26000 standard and ways are shown how the philosophy of CSR can be implemented in enterprises (DIN ISO 26000:2011).

Today an economic decision that runs counter to the expectations of corporate social and ethical responsibility may be detrimental to a company's reputation and its market success (Herbel \& Herbel, 2020; Peloso \& Travis, 2020). The negative impacts of such decisions may be actually completely detached from the corporate core business, as evidenced for example by the current case of "signalling technology for a coal-fired power plant" by the Siemens Group in Australia. "Given the devastating large-scale fires in Australia, this is a DEATHBLOW to Siemens' reputation. A corporation that is regularly securing orders in the order of billions in any currency now is being faced with public shaming because of an 18-million euro transaction " (Fromm, 2020). With the updates to liability law, recently also the liability risks for ethically questionable behaviour, as shown by Papula et al. (2014), have skyrocketed up to prison risks for managers and supervisory board members. The strategic alignment of corporate culture apparently also with a view to such risks has become a management task. A clear and unmistakable commitment to corporate values by the management today is deemed a core and essential prerequisite, not least because in the event of disputes and recourses, members of corporate boards are measured by this commitment. A strong statement of conformity by the management with the declared corporate culture underscores both the importance of the values and their binding nature (Lehner 2019). But even an explicit commitment to the values in itself apparently is not sufficient. Due to the many scandals around fraud and manipulation, doubts arise about actual real-life worth of the declared values. On the other hand, each case of irregularity lends itself to calls for regulatory measures and involvement of the lawmakers. But additional new acts of law and regulations, such as the German Transparency Directive Implementation Act (CSR-RUG of 17 April 2017) ultimately only are going to have an effect on succeeding in conveying the values these laws and regulations seek to implement to a wide audience of staff in companies. There are good signs that this may succeed. The respective prerequisite is a strategically aligned corporate culture that relies instead on fine words only on organisational implementation and individual internalisation of values (Ioannou \& Serafeim, 2020). In that, on the one hand the prerequisites need to be established for the ethical dimension of CSR to take hold in order to nurture corporate social responsibility while also promoting alignment with the strategy in the company. The classical approaches of risk management and risk controlling failed to prevent antitrust law violations and corruption, fraud and accounting-related offences (Cadbury Committee Report, 1992; Durst \& Henschel, 2020; Bistrova \& Lace, 2016). Consequently, it is not enough to rely on compliance statements and formal control systems but the conflicts of interest between economic and ethical values need to be discussed and addressed systemically (Eijsbouts, 2020; Gutterman, 2020). The current scandals thus raise the question about the meaning, viability and scope of values, and how the values can be implemented more effectively as a core integral part in corporate process flows for successful and sustainable corporate operations. The strategic alignment of the corporate culture in the process cannot be just managed unidirectionally in a top-down approach but there also has to be communication in the bottom-up direction. Prerequisite for this is a more consequent focus on dialogue with corporate internal and external stakeholders at all tiers of the organisation (Harrison \& Wicks, 2019). This is where the mid-management has a particularly important role. Remišová und Lašáková point out in their study this rethinking of corporate philosophy (Remišová \& Lašáková, 2016). This lays particular responsibility on managers as role models and promotors of values. Remišová and Lašáková use in this context the notion of a moral leader (Remišová \& Lašáková, 2013; Lašáková et al. 2013). The "ethical lead at the top" is, by the studies of Trevino, Brown and Hartman, of key importance (Treviño et al 2003). Weaver, Trevino and Agle determine in another study how and under what conditions managers may influence others to identify with the corporate culture (Weaver et al. 2005). For this, they deem as the top integrating element the code of conduct. Key in order for this ethical code to be effective is that the code's intentions and presentation style are convincing enough for managers and that they identify with the content. Above all however, they expect the higher management echelons they report to fully subscribe to these values as well, which needs to be proven by evidence. The individual values evolve in the company in a dynamic development process at three levels: the organisational level, the team level and the individual level. At each level, different processes take place, which however need to be mutually aligned 


\section{ENTREPRENEURSHIP AND SUSTAINABILITY ISSUES}

ISSN 2345-0282 (online) http://jssidoi.org/jesi/

2021 Volume 8 Number 4 (June)

http://doi.org/10.9770/jesi.2021.8.4(19)

in the process flows. The topics at each of the levels are different and level-specific (Erpenbeck, 2018). The core question at the organisational level is "How can the organisation define and continuously develop its common values?" (Erpenbeck \& Sauter, 2018) The question at the team level reads: "How can team-relevant values be built with a view to the team's strategic needs?" (Erpenbeck \& Sauter, 2018). On the individual level, the question that arises is: "How can personalised evaluation processes for all staff members be enabled with a view to the strategic needs of one's own work area?" (Erpenbeck \& Sauter, 2018).

The effect of values as a decision making aid is moderated by inter-individual and system-specific influences, as even values that are accepted and internalised do not necessarily guarantee a value-based collective behaviour (Kučera, 2020). The irregularities of the Dieselgate scandal occurred despite the company and its employees having subscribed, at least formally to corporate social responsibility (Werner, 2019). It can also be assumed that large parts of the workforce had internalised the values. For instance, many staff members were well aware of the ethically highly questionable nature of the diesel powertrain manipulations, but they were unable to assert their concerns in the company's hierarchy, whether out of fear of social ostracism, or because ethical conduct, if conflicting with economic aims, was latently or blatantly penalised in the system (Thompson, 2019). With a view to the newly established whistleblower systems, the aim for the future is to contain this risk (VW Group, Sustainability Report, 2017; VW Group, Shift Magazin, 2018). This additional organisational unit is part of a more comprehensive value management that must meet the challenge of integrating system-stabilising values from strategic all the way down to operative areas of the company. A prerequisite for this to succeed is for the organisational framework to be aligned with the values. Today it is a hard fact of business life that implementation of values is not just a moral and ethical question, but the value culture of a company also has an existential and economic aspect to it. These connections are underscored by the repercussions of the Dieselgate scandal. Considerations on how to reinforce the "ethical capital" today are in shareholder assemblies up to management boards and supervisory boards an increasingly prevalent topic. And, investors as well increasingly refer in their decisions to this "ethical capital" of companies (Groth, 2018; Stüttgen, 2017). This shift in importance and value shift has resulted in this concern having been addressed in some companies, such as the VW Group, also organisationally by management in that dedicated organisational units have been established at the management board level. While other corporate areas such as marketing and finance have been managed with the aid of robust management systems, there has been indeed a lack of controlling concepts for the implementation of corporate culture in this particular area of management board activities to mutually align the complex processes and structures with the pursued forms of conduct. In many companies, addressing non-conforming forms of conduct in legal terms still has been the primary focus, including also how by regulations, non-conforming and harmful conduct can be avoided, recognised early on (whistleblower systems) and penalised in the future (VW Group, Whistleblower System, 2021). Better chances of success as compared to pushing penalties are seen in approaches that aim at internalisation of values. In order to promote this process in a targeted manner, the question arises how the implementation and the level of presence of the values pursued in codes of conduct can be measured at the individual and organisational level.

Should it succeed to effectively use indicators of the level of presence of values in general and also applied to the specific requirements of each job and consequently to individual skills and competences, the threat of scandals could be substantially reduced. The first modest forms of value controlling can be found in sustainability reports. Such reports mostly refer to the principles of the Global Reporting Initiative (GRI) and its coefficients and indicators (Geschäftsstelle Deutsches Global Compact Netzwerk 2014). For value controlling though and the topics it includes, only indirect and non-specific conclusions can be expected on corporate "ethical capital" (Global Reporting Initiative 2000; Global Reporting Initiative 2016). This is where the strategic and operative challenges lie of a sustainability-focused value management. To coordinate, initiate and develop value controlling, at the organisational level the appointment is needed of a value management team. The team further also is in charge of analysing and maintaining the current corporate culture and advancing the value shift that can be expected as a result of the change processes. Key at all corporate levels though is that the values are 


\section{ENTREPRENEURSHIP AND SUSTAINABILITY ISSUES}

ISSN 2345-0282 (online) http://jssidoi.org/jesi/

2021 Volume 8 Number 4 (June)

http://doi.org/10.9770/jesi.2021.8.4(19)

communicated in a continuous top-down and bottom-up process. The model suggests involvement with the values on a continuous and active basis, thus extending far beyond formal cataloguing, description, identification and certification of values. This active involvement facilitates internalisation and continuous further development of values. This resolves the concerns of value management in its actual sense.

There is no lack of references in the literature to the internalization of values and an organization and management culture that is compatible with them. Particularly with a view to change management and coaching, a variety of approaches to influencing behaviour based on values are currently being discussed and scientifically supported (Stolzenberg \& Heberle, 2020; Webers, 2020; Lauer, 1999). These approaches have a long tradition and reach far back into the previous century. The social science approach to "organizational learning" has received special attention in this development. In this context, the question arose as to which structural prerequisites must be created for a suitable learning platform and how the acquired patterns of action can be stabilized. The studies focused primarily on the teaching of cognitive abilities, skills and knowledge. Studies on this can be found, for example, in the action theory of Argyris, who sought access via models of instrumental learning, focusing primarily on learners under specified structural conditions (Argyris, 1993; Argyris \& Schön, 1996). This study follows the CSR approach to corporate value. This shifts the importance of the learning plateau from cognitive to affective learning goals (Worbach et al, 2019). The CSR concept places high value-based demands on both companies and employees. A fundamental reorientation of this research approach aims at a consistent orientation of the implementation and internalization of values in a cyclical maturation process, which can be represented in development stages. The idea of a cyclical maturity process can also be found in other business management approaches, such as the life cycle of a company (Thommen et al., 2020) or in marketing concepts (Mishra, 2020; Stark, 2019). Inspired by these approaches, these thoughts were also transferred to the development of values in a company. Examples of this approach can be found in the historical-oriented development model according to Frederick (2008, 2006, 1994), the development model according to Visser (2011), the pyramid approach by Caroll (1979) and the maturity model according to Schneider (2015). These approaches emphasize the structural organizational approach but neglect the specifics of an individual and collective dimension to be delineated. Therefore, the aim of this study is to elaborate the interactions between organizational implementation and individual internalization of values in their mutual interdependencies as an independent dimension. In order to depict this process, the contents of this process, which determine the degree of organization on the one hand and the degree of maturity on the other, must be elaborated. The items for determining the degree of organization could be derived from ISO 26000:2011. A central, but not sufficient basis for determining the maturity level is the Code of Conduct. Unlike ISO 26000, which can be used to determine the degree of organization, there are no binding quality criteria and quality standards in the Codes of Conduct. These must be worked out and developed in the study. A Code of Conduct aims at a value-determined behaviour that indirectly describes, prescribes and demands ideal-typical behavioural patterns via a compilation of typical interpersonal action areas prioritized by the code. The behaviour underlying the behavioural patterns is value-determined and is influenced by situational circumstances. However, the effectiveness of these guiding principles depends on quality standards, which must first be developed in contrast to ISO standard 26000.

The investigation into the elaboration and development of quality standards is based on the consideration that the Codes of Conduct must be logical in themselves, appealing to the addressees, reflect the current state of the discussion on values, and be consistent and compatible with the structures, processes and incentive systems of the companies. The following research hypotheses are derived from this to determine the degree of maturity:

1. The attractiveness of the design and the relevance of the topics to the addressees are important prerequisites for ensuring that the "Code of Conduct" attracts interest and attention and that employees identify with these values.

2. In addition to the design, the topicality, completeness and weighting of the values and fields of action of the Code of Conduct are also decisive for its attractiveness. 


\section{ENTREPRENEURSHIP AND SUSTAINABILITY ISSUES}

ISSN 2345-0282 (online) http://jssidoi.org/jesi/

2021 Volume 8 Number 4 (June)

http://doi.org/10.9770/jesi.2021.8.4(19)

3. The corporate culture cannot be ordered unilaterally, but must be continuously communicated in an internal and external stakeholder dialog in a top down as well as bottom up process.

The 18 examined Codes of Conduct show serious deviations in structure, depth of content, design and other qualitative items. It is striking and noteworthy that companies that were particularly involved in scandals fundamentally revised their Codes of Conduct and developed special quality standards in the process. These comparably high quality standards for the Codes of Conduct were found primarily at companies that had a reputation with a recognized corporate culture. Based on an analysis of these documents and the expert interviews, authoritative items were developed that make up the quality standard of a Code of Conduct. This confirmed the first hypothesis of the study: "The attractiveness of the design and the relevance of the topics to the addressees are important prerequisites for ensuring that the Code of Conduct attracts interest and attention and that employees identify with these values." Successful companies, according to a further finding from the document analysis and the expert interviews, focused on updating the Codes of Conduct and involved the stakeholders in this process of changing values, promoting dialog with the internal and external stakeholders of the groups through varied communication platforms. Thus, the two further research approaches could be confirmed.

Further indications for describing and safeguarding the quality standard were found in the literature on the didactics of textbooks, on the comprehensible language of texts and laws, on indications for the structure and design of forms, and even on recommendations for the design of advertising texts.

\section{Methodology}

For purposes of this study, the method has been chosen of qualitative social research. The qualitative method suits the investigation aims as it exposes social reality in a world as perceived and experienced by the study participants (Flick, 2017; Lamnek, 2016; Merriam, 2009). In the course of the examination, document analysis was combined with the interview method (Mayerhofer 2009). Subject of the document analysis were 18 codes of conduct (primary documents) of the largest global automakers. As secondary references, an additional 410 documents were included in the analysis - statements, published interviews and business reports. The next step involved interviews with 32 experts about their particular experience in order to verify and clarify the findings and explore them in more detail. In choosing the documents and in interviewing the experts, biases and subjective setups and assessments were to be avoided by an explorative approach as well as a clear delimitation and definition of the scope of the examination.

As primary references for the document analysis, codes of conduct of 18 among the largest global automotive manufacturers (eight European, four U.S. and six Asian corporations) were included in the analysis. Further insights in the examination were supplied by legal analyses and pertinent reporting.

All the corporations included in the document analysis have a global scope of operations. Differentiation by continents of countries of origin nowadays does not make much sense anymore or provide additional information anyway due to the internationalised supply chains. For example German firms such as the BMW Group as well as the VW Group have their production sites in many countries and regions of the world, and the same goes for U.S. corporations such as Ford Motor Company and General Motors.

This internationalisation of large corporations necessitates despite the many differences in thinking and legal differences a value set that is equally valid in all continents and regions even despite their different legal systems. A code of conduct that imposes global rules of conduct for all parts of a corporation must, despite the wealth of many different cultural imprints, stances and latent and explicit legal standards, find a common denominator. 


\section{ENTREPRENEURSHIP AND SUSTAINABILITY ISSUES}

ISSN 2345-0282 (online) http://jssidoi.org/jesi/

2021 Volume 8 Number 4 (June)

http://doi.org/10.9770/jesi.2021.8.4(19)

As further important documents, sustainability reports of the companies were examined for the status of values declared in their codes of conduct. While a code of conduct specifies the desired forms of conduct, it was verified using the sustainability reports whether their findings match the declared intentions.

For the interviews, mostly experts were chosen from corporate units with cross-departmental scope of operations. In such functions, dealing successfully with the assigned tasks is contingent upon one's place in corporate hierarchy, powers assigned and the resources available. This pool of experience has been successfully explored and included in the examination. Through impulse questions, the experts were encouraged to report preferably freely about their work situation and pertinent challenges, and approaches to deal with these.

\section{Results}

In this study, quality norms have been identified and it has been shown which attributes define the appeal of a code of conduct. A code of conduct in this paper is defined as a collection of typical types of activities in human to human interactions that are prioritised in the code of conduct and for which the ideal forms of conduct are described, defined and enforced.

The codes of conduct of the companies explored meet these criteria and deal with selected practical guidelines, types of activities and core topics, as described also in ISO 26000. Which types of activities are prioritised in terms of scope and content depends on the issues faced by the particular company. The likelihood that these rules of conduct will be observed and the underlying values internalised will be higher, by the assumption of this study, where the codes of conduct in terms of content and scope are structured logically, in an appealing manner for the recipients and deal with values in a way that is up-to-date with latest insights in the general discussion on values. Further also they must be compatible with the structures, process flows and incentive systems of the company. To meet these needs, a number of questions need to be clarified, such as what defines the level of appeal of a code of conduct. Neither the German Transparency Directive Implementation Act of 11 April 2017 nor ISO 26000 provide specific guidelines, ideas or recommendations on this. Secondary literature on the CSR approach as well in general and the codes of conduct in particular do not provide any qualitative recommendations as to how and by what criteria a code of conduct needs to be structured and which quality norms promote identification of staff with the code. For that first, a pool of criteria was compiled from different sources.

The items derived and developed from the study are not only a sound aid for the development of the Codes of Conduct. They can also be used for an analysis of strengths and weaknesses in the context of benchmarking. However, these items are also an indispensable basis for coordinating the development steps of the organizational structural level with the personal level and for steering a sustainable stage-oriented development process. This succeeds because the degree of organization as well as the collective maturity level can be determined by quantifying the items. This process variable, which is introduced into the study, makes it possible to synchronize the development of the organizational and maturity levels and, with an energy expenditure that can be optimally controlled, to move effectively to a higher level. In this way, organizational resources are used optimally and human overload, defence mechanisms and frustrations are avoided. Based on these references, six evaluation aspects have been identified that have been assigned differentiating evaluation criteria. Specifically, these are the following six evaluation aspects with pertinent evaluation criteria:

- Formal design of the code of conduct, with the evaluation criteria of scope, date of first and follow-up publications, topicality, the topics addressed in the preface, structure of the preamble, layout of the table of contents, scope of topics, prioritisation of topics, verbal and non-verbal;

- Design, with the evaluation criteria of formal layout, font size and font type, spreading the flow of text with visual elements, how text is combined with visuals, and the page layout; 


\section{ENTREPRENEURSHIP AND SUSTAINABILITY ISSUES}

ISSN 2345-0282 (online) http://jssidoi.org/jesi/

2021 Volume 8 Number 4 (June)

http://doi.org/10.9770/jesi.2021.8.4(19)

- Comprehensibility and the language style used, with the evaluation criteria of simplicity, relevance and appeal to the recipient, formal structure and logical flow, brevity and conciseness, encouraging effect and dramaturgy;

- Visual and text layout, with the evaluation criteria of visuals that are relevant to the recipient, integration of visuals with text and colour style;

- Appeal to target groups that encourages identification with the message, with the evaluation criteria of realism and authenticity, motivating, challenging and instructional address, adequate style used and grammatical complexity.

- Didactic transformation, with the evaluation criteria of didactic transparency, arrangements that promote conveying the topics, variation of methods, media variety

The 18 codes of conduct were compared with each other using these evaluation criteria on a 10-point scale and verified for relevance to determine their level of appeal. The results with the total of six evaluation aspects and 36 evaluation criteria overall were comprised into two particularly relevant evaluation categories with a total of 15 criteria.

The central parameters of this management process, which is geared toward continuity and sustainability, are the degree of organization and the collective or individual maturity of the employees. Both areas of management must be steered toward an increasing level of social responsibility in a stakeholder dialog. The study was able to confirm the research hypothesis and it was possible to work out that the degree of attractiveness of the Code of Conduct favours the probability of internalization and implementation of the proclaimed and intended values of social responsibility in a sustainable and effective manner. The degree of effectiveness can be increased if, in addition, individual and collective qualification is geared toward the intended change in values in graduated and coordinated processes. These interrelationships have not yet been addressed either in basic scientific research or in corporate practice. Recommendations, standardizations and minimum standards for a didactically prepared Code of Conduct were found neither in the scientific literature nor in application-oriented research. The study was therefore unable to draw on any studies geared to this purpose and had to work out the basics for determining the degree of attractiveness of a Code of Conduct on its own. In doing so, findings from business education, learning psychology and communication sciences were used. The importance of scientific validation of the Codes of Conduct is becoming a recognized competitive factor for companies, probably also as a significant part of the strategic orientation of risk management. Since individual misconduct can become a risk that threatens the existence of the company, companies are focusing on preventive measures to implement and internalize the intended corporate values.

In this study, basic principles were worked out for this purpose in order to determine the degree of organization, which maps the structural organizational prerequisites (e.g., organizational structure, process organization and business processes), and to determine the degree of maturity. To this end, binding quality standards for the Codes of Conduct first had to be developed - comparable to ISO standard 26000. In a further step, the items developed were combined to form assessment clusters. These evaluation clusters allow thematic focal points to be identified and profiles to be drawn up for benchmarking and the company's internal fields of action. By quantifying the level of organization and maturity, it is possible to effectively steer and optimize the development process toward a higher level of social responsibility. This makes it possible to map the interdependencies between structural organizational conditions and the development of individual and collective developments in a model, thus placing the maturity (Schneider) or pyramid (Caroll) model on an empirical basis. Both dimensions can be represented in this developed model in their mutual dependence. In order to further harmonize the results and recommendations for action, these findings should be backed up with quantitative social research methods. The methodological prerequisites necessary for this are given by the content-related determination and quantification of the items and can be considered clarified for the in-depth quantitative investigation. On this data plateau, three major delimitable research approaches can be identified. First, the items and clusters underlying the degree of 


\section{ENTREPRENEURSHIP AND SUSTAINABILITY ISSUES}

ISSN 2345-0282 (online) http://jssidoi.org/jesi/

2021 Volume 8 Number 4 (June)

http://doi.org/10.9770/jesi.2021.8.4(19)

organization and maturity must be checked for completeness, reliability and validity using suitable statistical methods such as correlation, regression and factor analysis. In a further research approach, the correlations and dependencies between the degree of attractiveness of the Code of Conduct on the one hand and the identification with the intended values on the other should be worked out using correlation and regression analyses. Such an analysis can be expected to provide a more reliable prediction of the effects of the degree of attractiveness on identification with the intended values. What has been elaborated in this qualitative study through experts and documentation analysis can be more precisely determined and verified through this quantitative analysis. Then the resources for systemic control of the development steps can be optimized and the benefits of these measures can be predicted more precisely. This is especially true for the verification of the elaborated step-related development model. In the context of this question it is to be worked out, which effects on the working climate, on the achievement orientation and on the psychological load are to be counted on, if the development steps exceed the tolerance range to be defined between organization and/or degree of maturity. Two different variants can be assumed here: In the first variant, a higher degree of organization is to be assumed, and in the second variant, a higher degree of maturity. Another variable to be included in this study design is the influence of management and management tools such as risk analysis and operational integration management. For the risk and value management of a company, these investigations are important and central concerns.

\section{Evaluation category 1: Formal Design of the Code of Conduct}

What does the organisation do, ... (or, what can we do ...)

1.1. To promote the content of the code of conduct with an appealing design that is appropriate for the recipients.

1.2. To structure the code of conduct clearly and in an appealing manner for the reader.

1.3. To improve the appeal of the code of conduct to preferably many groups of employees in the company.

1.4. To adjust linguistic presentation for simplicity, a clear inner and outer structure, brevity/conciseness and encouraging effect.

1.5. To develop an up-to-date and appealing design in how the code of conduct is presented.

1.6. To convey complex interdependencies in a comprehensible manner and to avoid overwhelming the reader.

1.7. To facilitate active exploration of the topic.

\section{Evaluation category 2: Didactic Design of the Code of Conduct}

What does the organisation do, ... (or, what can we do ...)

2.1. In order to design the code of conduct in an appealing manner.

2.2. To encourage employees to actively deal with the target values.

2.3. To devise up-to-date training methods.

2.4. To use available media mainly in the digital sphere.

2.5. To promote the development and consolidation of affective learning objectives (such as multimedia approaches, training-on-the-job, e-learning).

2.6. To promote and sustain the processes of internalisation of values.

2.7. To find the right words to address staff with.

2.8. To promote and communicate the target values on the basis of value management.

The appeal of a code of conduct further also depends on how the values are updated and carried further. Consequently, the question was explored whether, how and at which points a value shift in the present codes of conduct and any earlier versions of the codes may be identifiable and what consequences can be derived from this. Conclusive information in this first step was delivered by a comparison of the current codes with their earlier versions, such as the 2015 version of the code of conduct of the BMW Group, its 2016 version and the current 2019 version, as well as the 2010 and 2017 versions of the code of conduct of the VW Group. These versions were compared for changes from formal updates (such as changes in members of the management board with follow-up update of the preface to the code of conduct to reflect the changes) to substantive updates that reflect 


\section{ENTREPRENEURSHIP AND SUSTAINABILITY ISSUES}

ISSN 2345-0282 (online) http://jssidoi.org/jesi/

2021 Volume 8 Number 4 (June)

http://doi.org/10.9770/jesi.2021.8.4(19)

the value shift. Although the management board member in VW signed under the preface was replaced, neither the preface in the codes was updated nor new focus points were set by the new management board. This detail though may well have caused irritations among corporate staff, being viewed as a lacking sign of progress in focus, all the more so as the old management board member has been associated with the Dieselgate scandal. In terms of substance, the BMW Group updated its code between 2015 and 2016 with new additions in two places, and the 2019 version contains changes in four places. In contrast the code of the VW Group saw between the 2010 and 2017 versions a comprehensive update in terms of both form and substance. The level of appeal as defined by the evaluation criteria posited in the first part above was markedly improved. There were also a number of additions, more detailed specifications and changed priorities. There was a major shift in priorities, with economic and social concerns having been declared equal in importance. This amounts to a fundamental shift in values which directly impacts many other values, whether in terms of having been reclassified in weight, or in that new values were added. With the newly added note that employees are a part of the company but also of society at large, the code of conduct signals a more decisive move towards corporate social responsibility. From this part of the examination, the following assessment criteria were derived.

\section{Evaluation category 3: Content Design of the Code of Conduct}

What does the organisation do, ... (or, what can we do ...)

3.1. To incorporate social responsibility in the core subjects, practical guidelines and rules of conduct.

3.2. To align the range of topics and the topic focus points to the current business challenges.

3.3. To update the content of the code of conduct and to adjust it for societal developments.

3.4. To integrate stakeholders into the value process.

The core topics and types of activities are subject to constant change that reflects the different needs and interests of the stakeholder groups. A key question was who and how is classified by the companies as a relevant stakeholder group and how the communication processes are organised. This is done by the VW Group in an elaborate process (Birri, 2014). The company has included its stakeholders in a matrix according to priority and topics and adjusted its dialogue with stakeholders for the matrix accordingly. From this analysis, the following evaluation category follows with its assigned criteria:

\section{Evaluation category 4: Value-Based Exchange of Information and Experience with External Stakeholders}

What does the organisation do, ... (or, what can we do ...)

4.1. To ensure a systematic acquisition of information.

4.2. To preferably account for all relevant stakeholders and prioritise these in terms of their significance to corporate policy.

4.3. To analyse the needs and expectations of stakeholders.

4.4. To systematically structure the dialogue with stakeholders via exchange and dialogue platforms.

4.5. To organise partnerships with the most important stakeholder groups.

4.6. To support managers in their function as promotors of values ("Moral Leadership") and role models with pertinent responsibilities.

4.7. To identify and eliminate non-conforming behaviour early on.

On how business processes and the organisational structure are aligned with the pursued corporate culture, mainly experts were approached that by virtue of their job were in charge as management representatives of the different cross-departmental functions such as occupational health \& safety, health management and others. Additionally, contributions in professional periodicals and interviews published by the media were referred to. The interviews with the experts focused on integration of the values into the organisational structure and their prioritisation in daily business decisions. The experts pointed out in the interviews where and how in the organisational structure improvement potentials could be exploited in a more sustained manner. On the example of whistleblower systems, the defining attributes were determined in dialogue with the experts of structures and process flows for continuous further development of corporate culture. From this, four evaluation categories with a total of 25 evaluation criteria were derived: 


\section{ENTREPRENEURSHIP AND SUSTAINABILITY ISSUES}

ISSN 2345-0282 (online) http://jssidoi.org/jesi/

2021 Volume 8 Number 4 (June)

http://doi.org/10.9770/jesi.2021.8.4(19)

\section{Evaluation category 5: Organisational Structure}

What does the organisation do, ... (or, what can we do ...)

5.1. To create the function of a management committee.

5.2. To implement a coordination board for sustainability.

5.3. To involve workgroups in the implementation of values.

5.4. To advance projects by means of project groups for priority topics.

5.5. To establish in the organisation the function of a management representative for sustainability activities and to place it as a board function near the head of the institution.

\section{Evaluation category 6: Organisational Procedures and Business Processes}

What does the organisation do, ... (or, what can we do ...)

6.1. To endow the management representatives with information competence, competence to give instructions, decision making competence, advisory competence and budget competence.

6.2. To reinforce personal powers for cross-departmental functions (safety at work, diversity management etc.).

6.3. To provide sufficient resources in terms of time and personnel (e.g. also including bundling of tasks of the same type)

6.4. To provide sufficient financial resources, which also can be coordinated across departments.

6.5. To communicate the role model function of organisational management in suitable formats to the personnel.

6.6. In order to establish the value framework of social responsibility in guidelines and to integrate these in the organisation (value days, employee feedback etc.)

\section{Evaluation category 7: Alignment of Social Responsibility}

What does the organisation do, ... (or, what can we do ...)

7.1. To adjust the mission, vision, values, guidelines and forms of conduct accordingly for the value shift.

7.2. To include social responsibility in strategic planning.

7.3. To establish social responsibility as a key part of corporate identity.

7.4. To implement value management.

7.5. To align values and guidelines for conduct with corporate policy and organisational strategies.

7.6. To use comparisons with the best for continuous improvement.

\section{Evaluation category 8: Controlling}

What does the organisation do, ... (or, what can we do ...)

8.1. To devise indicators for economic, environmental and social criteria.

8.2. To be able to consider input and output as well as the outcome and long-term measurements of effects as a decision making basis in strategic alignment.

8.3. To control developments by means of a PLANNED/ACTUAL analysis and to mitigate irregularities in time.

8.4. To incorporate the issue of long-term viability into decision making processes (e.g. by means of budget surveillance across fiscal periods).

8.5. To pursue external certification for the sake of increasing credibility.

8.6. To manage the continuous improvement process in coordination with stakeholders.

8.7. To assess the effects of training schemes and human resources development programmes relative to the costs incurred (e.g. through observation and cost/benefit analyses).

8.8. To regularly analyse its current and future need of personnel, with a view to the needs and expectations of stakeholder groups.

The individual and collective internalisation of values can be reinforced and safeguarded through suitable personal growth measures. As ethical potential varies between individuals in the same way as cognitive abilities 


\section{ENTREPRENEURSHIP AND SUSTAINABILITY ISSUES}

ISSN 2345-0282 (online) http://jssidoi.org/jesi/

2021 Volume 8 Number 4 (June)

http://doi.org/10.9770/jesi.2021.8.4(19)

do, staff members react to the value shift at the individual level in very different ways. Analogously to "human capital" (Birri, 2014) that refers to professional capabilities, teamwork skills, soft skills and personal commitment of the workers employed by the company, this examination included an extended focus on corporate 'ethical capital'. In this respect, recruiting and corporate qualification measures on, off and near the job need to focus more alongside professional aspects on values. This also includes indicating in a more detailed and specific manner the ethical requirements of a job already in job descriptions and job profiles. A stronger emphasis on values affects the design of all personnel recruitment and selection systems. From this part of the analysis, two evaluation categories were derived with a total of 11 evaluation criteria.

\section{Evaluation category 9: Training Initiatives}

What does the organisation do, ... (or, what can we do ...)

9.1. To plan training activities.

9.2. To convey the communication techniques for dealing with risks and conflicts of interest.

9.3. To implement CSR values in the organisation and actively practice the values (e.g. value days, bonus schemes, volunteer days, training courses)

9.4. To align the values and guidelines for conduct with management tools such as the remuneration system, target agreements, management feedback.

9.5. To develop personal qualification and development plans for all staff members and to ensure that the use of personnel is adequate to the requirements and their respective skills and abilities with regard to the target values.

9.6. To establish in the organisation a value-based reflection of self-perception and perception by others, and to develop it further.

Evaluation category 10: Recruitment and Human Resources Management in Accordance with the Requirements and Skills and Abilities

What does the organisation do, ... (or, what can we do ...)

10.1. To identify and document the potential of every single employee and of the organisation with regard to the values pursued.

10.2. To align recruitment and career advancement concepts for the development of values with current and future organisational and individual requirements.

10.3. To develop and maintain a training concept in alignment with the need for personnel and human resources management that builds on current and future organisational and individual requirements.

10.4. To support and provide training-in for new staff members in securing and developing their value-based potential (e.g. through mentoring, coaching, tutoring, work assignment, human resources development),

10.5. To promote workplace mobility (internal and external).

\section{Conclusions: Requirements for Value Management for Continuous Internalisation and Implementation of Values}

An appealing code of conduct is for the "ethical lead at the top" of a company a core prerequisite, as the management's commitment to ethical values is the higher the better the level of appeal of the code of conduct. This commitment has a positive and sustained effect on the implementation of values and their internalisation if...

1. The code of conduct has a high level of appeal in terms of being up-to-date, its design, relevance to recipients and scope in terms of the range of topics included;

2. The values declared in the codes of conduct are continuously adapted and updated at the strategic and operative levels in accordance with societal value shift and the requirements of social responsibility;

3. The management personally declares its commitment to the code and the code as a management task, and the institutional framework including the corporate hierarchy, sequences of activities, processes and management systems (such as the incentive system) are aligned to be compatible with corporate culture; 


\section{ENTREPRENEURSHIP AND SUSTAINABILITY ISSUES}

ISSN 2345-0282 (online) http://jssidoi.org/jesi/

2021 Volume 8 Number 4 (June)

http://doi.org/10.9770/jesi.2021.8.4(19)

4. The target values of a company are communicated in a suitable form to internal and relevant external stakeholders, and accepted and shared by these;

5. The individual and collective internalisation of values is aided by auxiliary training and education activities, sustained by a coherent HR concept (internal and external recruitment, use of personnel) and continuously developed through success checks.

From these five premises, the evaluation scales provided above were derived and conceived. These can be used as part of self-evaluation at all levels in a company for continuous further development and implementation of values by employees, teams and project groups. But also, these scales are a reference basis for strategic value management. As companies and organisational units differ in the attained level of ethical awareness and their development stages, the aim of value management is to actively shape this development process so as to reach a higher stage in the hierarchy of values. Schneider developed in this context the maturity level model and Caroll his pyramid model (Schneider, 2012; Carroll, 1979). The models by Schneider and Caroll share in common that in both, values develop towards higher maturity levels. As an insight from the expert interviews in this study, it has been found that this development process towards refinement and stabilisation of values relates to two distinct focus areas. These are designated in this study as organisational development level (evaluation categories 5, 6, 7, 8 ) and maturity level (evaluation categories 1, 2, 3, 4, 9, 10). The organisational development level refers to the organisational prerequisites that must be met in order for values to effectively take hold in the company, while the maturity level represents the internalisation of values. Every criterion to determine the organisational development level is assigned in a six-step quantification procedure a rating on the scale from 1 to 100 . The determined values on the scale for the different criteria are provided in a partial result for each evaluation category and comprised in the next step into the summary value of the "organisational development level" on a six-grade scale. The total value of the organisational development level thus is the weighted mean of the four evaluation categories. From this detailed analysis, it can be concluded in which particular areas lie the respective strengths and weaknesses of a company, and which areas sustainable value management should focus on. The evaluation of the maturity level is performed analogously. The reference basis in this case are the six evaluation categories with a total of 37 criteria, which are also run through in a six-step quantification procedure. The six stages to describe the maturity level were developed in reference to the classification of affective values by Bloom and Krathwohl (Krathwohl et al., 1978). Each stage designates an attained individual and/or collective maturity level. The specific value of the maturity level so far can only be concluded on indirectly. Direct measurement and/or assessment of the values using for instance the classification of values as common in analogous approaches in personnel selection and recruitment with the aid of cognitive rating for abilities, competences and soft skills presents companies and specifically personnel recruitment with a substantial and as of yet unresolved challenge (Meixner, 2015). Because of this, this examination had to remain restricted to the indirect indicators listed above.

Prerequisite to continuous development of values is that both the organisational development level and maturity level are at a roughly identical development stage. Where the difference between the organisational development level and maturity level exceeds in the development process a certain critical margin, with either of them deviating excessively from what is deemed an appropriate status for the other, irregularities, irritations and emotional blocks are to be expected. These obstruct the process of change. This dynamic model relies for its relevance on interactions that have been comprised into eight premises. The development process occurs in a recurring mutual adjustment between the organisational development level and maturity level. Both should develop within a predefined tolerance range. All along, the existing mutual interdependencies need to be exploited that exist between the two areas. For instance the resources, organisational structures and process flows on the one hand shape the conduct of staff (being creates awareness), while on the other the conduct of staff shapes the organisational structures and processes.

\section{Final remarks}

It has been shown in the study that a coherent and didactically structured code of conduct that reflects current societal values is for a successful cultural change a core prerequisite, which though by itself is not sufficient. In 


\section{ENTREPRENEURSHIP AND SUSTAINABILITY ISSUES}

ISSN 2345-0282 (online) http://jssidoi.org/jesi/

2021 Volume 8 Number 4 (June)

http://doi.org/10.9770/jesi.2021.8.4(19)

order to raise awareness of employees about social responsibility, other prerequisites must be met as well. These prerequisites are referenced by the developed evaluation categories. As enablers with the meaning of a TQM system, they are a core part of a sustainable and process-based value management (Luthra et al., 2020; Kiran 2016).

\section{References}

Amtsblatt der Europäischen Union [Official Journal of the European Union] (2014). Guidelines. Directive 2014/95 / EU of the European Parliament and of the Council of October 22, 2014 amending Directive 2013/34 / EU with regard to the disclosure of non-financial and diversity information by certain large companies and groups.

Argyris, C. (1993). Knowledge for Action. A Guide to Overcoming Barriers to Organizational Change. San Francisco: Jossey-Bass Wiley. ISBN 1555425194.

Argyris, C.; Schön, D. A. (1996). Organizational Learning II. Boston: Addison-Wesley. ISBN 0201629836.

Baumgartner, A. A. (2020) A Conceptual Framework of Strategic Corporate Social Responsibility: A Model for Fulfilment of Societal Needs While Increasing Business Financial Performance. In: Farache, F.; Grigore, G.; Stancu, A.; McQueen, D. (eds.): Values and Corporate Responsibility. CSR and Sustainable Development. London: Palgrave Macmillan, p. 165-185. ISBN 978-3-030-52465-4. DOI 10.1007/978-3-030-52466-1.

Birri, R. (2014). Human Capital Management. Ein praxiserprobter Ansatz für ein strategisches Talent Management [Human capital management. A tried and tested approach to strategic talent management]. 2nd revised edition. Wiesbaden: Springer Gabler. ISBN 9783834945747.

Bistrova, J.; Lace, N. (2016). CSR Initiatives Introduction Status in Central and Eastern Europe and Their Importance for the Equity Investor. In: Idowu, S. O. Key Initiatives in Corporate Social Responsibility. Global Dimension of CSR in Corporate Entities. Switzerland: Springer international, p. 43-70. ISBN 9783319216409. DOI 10.1007/978-3-319-21641-6_3.

BMW Group (2015). Legal Compliance Code. Compliance. Driving the Right Way. Munich: Self-published.

BMW Group (2016). Legal Compliance Code. Compliance. Driving the Right Way. Munich: Self-published.

BMW Group (2019). Legal Compliance Code. Compliance. Driving the Right Way. Munich: Self-published.

Bowen, H. R. (1953). Social Responsibilities of the Businessman, New York: University of Iowa Faculty Connections.

Bundesrat [Federal Council] (2016). Gesetzentwurf der Bundesregierung. Entwurf eines Gesetzes zur Stärkung der nichtfinanziellen Berichterstattung der Unternehmen in ihren Lage- und Konzernlageberichten (CSR-Richtlinie-Umsetzungsgesetz) [Bill of the federal government. Draft of a law to strengthen the non-financial reporting of companies in their management and group management reports (CSR Directive Implementation Act)]. 23.09.2016. Printed matter: 547/16.

Bundesrat [Federal Council] (2017). Gesetzesbeschluss des Deutschen Bundestages. Gesetz zur Stärkung der nichtfinanziellen Berichterstattung der Unternehmen in ihren Lage- und Konzernlageberichten (CSR-Richtlinie-Umsetzungsgesetz) [Legislative resolution of the German Bundestag. Act to strengthen the non-financial reporting of companies in their management and group management reports (CSR Directive Implementation Act)]. 10.03.2017. Printed matter 201/17.

Buschmann, R.; Dahlkamp, J.; Latsch, G.; Schmitt, J. (2018). Die Frau, die zu viel wusste [The woman who knew too much]. Der Spiegel, 2018(25), p. 58-65.

Cadbury Committee Report (1992). The financial aspects of corporate governance. London: Self-published. ISBN 85258913.

Camilleri, M. A. (2016). Corporate Social Responsibility Reporting in Europe. In: Idowu, S. O. (ed.). Key Initiatives in Corporate Social Responsibility. Global Dimension of CSR in Corporate Entities. Switzerland: Springer International, p. 21-42. ISBN 9783319216409. DOI 10.1007/978-3-319-21641-6_2. 


\section{ENTREPRENEURSHIP AND SUSTAINABILITY ISSUES}

ISSN 2345-0282 (online) http://jssidoi.org/jesi/

2021 Volume 8 Number 4 (June)

http://doi.org/10.9770/jesi.2021.8.4(19)

Carroll, A. B. (1979). A tree-dimensional conceptual model of corporate social performance. Academy of Management Review, 4(4), p. 497-505. DOI 10.5465/amr.1979.4498296.

DIN ISO 26000:2011 (2011). DIN ISO 26000. Leitfaden zur gesellschaftlichen Verantwortung [Social Responsibility Guide] (ISO 26000:2010). Published by Deutschen Institut für Normung, Berlin.

dpa, aerzteblatt.de (2018). Krebsmedikamente gepanscht: Zwölf Jahre Haft für Apotheker [Cancer drugs adulterated: Twelve years imprisonment for pharmacists]. Retrieved 18.03.2021, from https://www.aerzteblatt.de/nachrichten/96287/Krebsmedikamente-gepanschtZwoelf-Jahre-Haft-fuer-Apotheker

Durst, S.; Henschel, T. (2020). Knowledge Risk Management - State of Research. In: Durst, S.; Henschel, T. (eds.). Knowledge Risk Management. From Theory to Praxis. Switzerland: Springer International, p. 3-10. ISBN 978-3-030-35120-5. DOI 10.1007/978-3-030$35121-2$.

Eijsbouts, A. J. (2020). Corporate Governance and Responsibility as Drivers of Sustainability. In: Rae L.; Roger M. (eds.). Corporate Social Responsibility - Sustainable Business: Environmental, Social and Governance Frameworks for the 21st Century. Neatherlands: Wolter Kluwer, p. 3-35. ISBN 9789403522302.

Erpenbeck, J. (2018). Werte, Wertungen. Das Buch der Grundlagen für Bildung und Organisationsentwicklung [Values, evaluations. The book of the basics for education and organizational development]. Heidelberg/Berlin: Springer. ISBN 9783662547762.

Erpenbeck, J.; Sauter, W. (2018). Wertungen, Werte - Das Fieldbook für ein erfolgreiches Wertemanagement [Ratings, values - the fieldbook for successful value management]. Berlin/Heidelberg: Springer. ISBN 9783662547786.

Flick, U. Qualitative Sozialforschung. Eine Einführung [Qualitative social research. An introduction]. $8^{\text {th }}$ edition. Hamburg: Rowohlt. ISBN 9783499556944.

Frederick, W. C. (1994). From CSR1 to CSR2. Business and Society, 33(2), p. 150-164. DOI 10.1177/000765039403300202. ISSN 00076503.

Frederick, W. C. (2006). Corporation, be Good! The Story of Corporate Social Responsibility. Indianapolis: Dog Ear Publishing. ISBN 9781598581034.

Frederick, W. C. (2008). Corporate Social Responsibility. Deep Roots, Flourishing Growth, Promising Future. In: Crane, A.; McWilliams, A.; Matten, D.; Moon, J.; Siegel, D. S. The Oxford Handbook of Corporate Social Responsibility. United Kingdom: Oxford University Press, p. 522-531. ISBN 9780199573943. DOI 10.3389/fpsyg.2016.00129.

Fromm, T. (2020): Kohlebergwerk in Australien: Ein GAU für die Reputation von Siemens [Coal mine in Australia: a meltdown for Siemens' reputation]. Süddeutsche Zeitung, 03.01.2020.

GESCHÄFTSSTELLE DEUTSCHES GLOBAL COMPACT NETZWERK [GERMAN GLOBAL COMPACT OFFICE] (2014). Verbindungen schaffen: Nutzung der GRI G4 Leitlinien zur Berichterstattung über die Global Compact Prinzipien [Creating connections: Use of the GRI G4 guidelines for reporting on the Global Compact principles]. Berlin: Self-published.

Geschäftsstelle Deutsches Global Compact Netzwerk [Office of the German Global Compact Network] (2014). Verbindungen schaffen: Nutzung der GRI G4 Leitlinien zur Berichterstattung über die Global Compact Prinzipien [Creating connections: Use of the GRI G4 guidelines for reporting on the Global Compact principles]. Berlin: Self-published.

Gesetz zur Stärkung der nichtfinanziellen Berichterstattung der Unternehmen in ihren Lage- und Konzernlageberichten (CSR-RichtlinieUmsetzungsgesetz - CSR-RUG) [Act to strengthen the non-financial reporting of companies in their management and group management reports (CSR Directive Implementation Act - CSR-RUG)] of 11. April 2017.

Global Reporting Initiative (2000). RG. Sustainability Reporting Guidelines, Amsterdam: Self-published.

Global Reporting Initiative (2016). GRI 101: Foundation, Amsterdam: Self-published. ISBN 9789088660955.

Grigore, G.; Stancu, A.; Farache, F.; McQueen, D. (2020). Corporate Responsibility and the Value of Value(s). In: Farache, F.; Grigore, G.; Stancu, A.; McQueen, D. (eds.): Values and Corporate Responsibility. CSR and Sustainable Development. London: Palgrave Macmillan, p. 1-13. ISBN 978-3-030-52465-4. DOI 10.1007/978-3-030-52466-1. 


\section{ENTREPRENEURSHIP AND SUSTAINABILITY ISSUES}

ISSN 2345-0282 (online) http://jssidoi.org/jesi/

2021 Volume 8 Number 4 (June)

http://doi.org/10.9770/jesi.2021.8.4(19)

Groth, J. (2018). Nachhaltiges Investmenents - Immer mehr Großanleger legen Wert auf ESG - Kriterien [Sustainable investments - More and more large investors are attaching importance to ESG criteria]. Retrieved 18.03.2021, from https://www.handelsblatt.com/finanzen/anlagestrategie/nachhaltigegeldanlage/umweltschutz-und-ethik-nachhaltige-investments-immer$\underline{\text { mehr-grossanleger-legen-wert-auf-esg-kriterien-/23246392.html?ticket=ST-58024-OOA }}$

Gutterman, A.S. (2020). Corporate Governance and Sustainability. In: Rae L.; Roger M. (eds.). Corporate Social Responsibility Sustainable Business: Environmental, Social and Governance Frameworks for the 21st Century. Neatherlands: Wolter Kluwer, p. 195-220. ISBN 9789403522302.

Harrison, J. S.; Wicks, A. C. (2019): Stakeholder Management: A Managerial Perspective. In: McWilliams, A.; Rupp, D. E.; Siegel, D. S.; Stahl, G. K.; Waldman D. A. The Oxford Handbook of Corporate Social Responsibility: Psychological and Organizational Perspectives. Oxford: Oxford University Press, p. 433-451. ISBN: 9780198802280. DOI: 10.1093/oxfordhb/9780198802280.013.19.

Herbel, P.; Herbel, E. (2020). The Business Case for CSR, ESG and Responsible Business. In: Rae L.; Roger M. (eds.). Corporate Social Responsibility - Sustainable Business: Environmental, Social and Governance Frameworks for the 21st Century. Neatherlands: Wolter Kluwer, p. 36-74. ISBN 9789403522302.

Ioannou, I.; Serafeim, G. (2019): The Consequences of Mandatory Corporate Sustainability Reporting. In: McWilliams, A.; Rupp, D. E.; Siegel, D. S.; Stahl, G. K.; Waldman D. A. The Oxford Handbook of Corporate Social Responsibility: Psychological and Organizational Perspectives. Oxford: Oxford University Press, p. 452-489. ISBN: 9780198802280. DOI: 10.1093/oxfordhb/9780198802280.013.20.

Ji, S.; Ihsan, J. (2019). The Impact of Perceived Corporate Social Responsibility on Frontline Employee's Emotional Labor Strategies. Sustainability, 11(2019), 1780. DOI 10.3390/su11061780.

Kiran, D. R. (2016). Total Quality Management: Key Concepts and Case Studies. US: BPS Books. ISBN 9780128110355.

Krathwohl, D. R.; Bloom, B. S.; Masia, B. B. (1978). Taxonomie von Lernzielen im affektiven Bereich. Weinheim: Beltz. ISBN 9783407510853.

Krichel, A. (2020). Textlose Bilderbücher: Visuelle Narrationsstrukturen und erzähldidaktische Konzeptionen für die Grundschule [Textless picture books: visual narrative structures and narrative didactic concepts for primary schools]. Volume 2. Published by J. Fay, C. Führer, J. Mayer, T. Rinker, Münster/New York: Waxmann. ISBN 9783830940838.

Kučera, D. (2020). A Historical Approach to Understanding Values and Its Importance for Corporate Responsibility. In: Farache, F.; Grigore, G.; Stancu, A.; McQueen, D. (eds.): Values and Corporate Responsibility. CSR and Sustainable Development. London: Palgrave Macmillan, p. 67-85. ISBN 978-3-030-52465-4. DOI 10.1007/978-3-030-52466-1.

Lamnek, S. (2016). Qualitative Sozialforschung. 6st revised edition. Weinheim: Beltz. ISBN 9783621282697.

Lašáková, A.; Remišová, A.; Kirchmayer, Z. (2016). Are Managers in Slovakia Ethical Leaders? Key Findings on the Level of Ethical Leadership in the Slovak Business Environment. Periodica Polytechnica Social and Management Sciences, 25(2), p. 87-96. DOI 10.3311/PPso.9758.

Lašáková, A.; Remišová, A.; Pučko, D. (2013). Culture and Leadership Preferences in Slovakia and Slovenia: Comparative Study Based on the GLOBE Student Research. Ekonomický casopis, 61(4), p. 376-395.

Lauer, T. (1999). Change Management. Fundamentals and Success Factors. Berlin, Heidelberg: Springer. ISBN 9783662621868. DOI 10.1007/978-3-662-62187-5

Lehner, U. quotes from Telekom AG. (2019). Deutsche Telekom verkleinert den Vorstand [Deutsche Telekom is downsizing its board of directors]. Written by Schwinge, M., press release from 02.05.2019, retrieved 18.03.2021, from https://www.telekom.com/de/medien/medieninformationen/detail/deutsche-telekom-verkleinert-den-vorstand-573088

Luthra, S.; Garg, D.; Agarwal, A.; Mangla S. K. (2020). Total Quality Management (TQM): principles, methods and application. Oxon: CRC Press. ISBN 9780367512835.

Mayerhofer, W. (2009). Das Fokusgruppeninterview [The focus group interview]. In: Buber, R.; Holzmüller, H. H. (ed.). Qualitative Marktforschung. Konzepte - Methoden - Analysen [Qualitative market research. Concepts - Methods - Analyzes]. 2nd edition. Wiesbaden: Gabler, p. 477-490. ISBN 9783834909763. DOI 10.1007/978-3-8349-9441-7_30. 


\section{ENTREPRENEURSHIP AND SUSTAINABILITY ISSUES}

ISSN 2345-0282 (online) http://jssidoi.org/jesi/

2021 Volume 8 Number 4 (June)

http://doi.org/10.9770/jesi.2021.8.4(19)

Meck, G. (2017). Totalschaden [Total loss].Frankfurter Allgemeine Sonntagszeitung, 23.07.2017, p. 21.

Meixner, H.-E. (2015). Der richtige Mitarbeiter am richtigen Platz zum richtigen Zeitpunkt - Vom Bewerber zum Umworbenen [The right employee in the right place at the right time - from applicant to candidate]. DÖD, 2015(2), p. 34-39.

Merriam, S. B. (2016). Qualitative Research: A Guide to Design and Implementation. $4^{\text {th }}$ edition. San Franzisco: Jossey-Bass. ISBN 9780470283547.

Mishra, N. (2020). Marketing Management. Agra: SBPD Publishing House. ISBN 9789350475690.

Mkrttchian, V.; Berezin, A.; Berezin, A. A.; Veretekhina, S.; Bershadsky, A.; Potapova, I. (2019). Model of Benchmarking for Development of Firm's Competitive Advantage to Improve Economic Growth in Cities. In: Benna, U. G. (ed.). Optimizing Regional Development Through Transformative Urbanization. Hershey, PA: IGI Global. ISBN 9781522554486. DOI 10.4018/978-1-5225-54486.ch006.

Osemeke, L.; Adegbite, S.; Adegbite, E. (2016). Corporate Social Responsibility Initiatives in Nigeria. In: Idowu, S. O. Key Initiatives in Corporate Social Responsibility. Global Dimension of CSR in Corporate Entities. Switzerland: Springer international, p. 357-376. ISBN 9783-319216409. DOI 10.1007/978-3-319-21641-6_17.

Papula, J.; Papulová, Z.; Papula, J. (2014). Konkurenčné stratégie tradičné prístupy vs. nové pohl'ady a techniky [Competitive strategies vs. traditional approaches. New perspectives and techniques]. Bratislava: Wolters Kluwer. ISBN 9788081680113.

Peloso, M.; Travis, H. (2020). Corporate Social Responsibility Reporting. In: Rae L.; Roger M. (eds.). Corporate Social Responsibility Sustainable Business: Environmental, Social and Governance Frameworks for the 21st Century. Neatherlands: Wolter Kluwer, p. $221-253$. ISBN 9789403522302.

Remišová, A.; Lašáková, A. (2013). Ethical Leadership Styles of Future Managers in Central and Eastern European Countries. International Journal of Applied Behavioral Economics (IJABE), 2(1), p. 30-50. ISBN 9781466631618. DOI 10.4018/ijabe.2013010103.

Schlick, L. (2019). Umfrage: Kaum Vertrauen in die Banken [Little trust in the banks]. retrieved 18.03.2021, from https://www.capital.de/wirtschaft-politik/umfrage-kaum-vertrauen-in-die-banken

Schneider, A. (2012). Reifegradmodell CSR - eine Begriffsklärung und -abgrenzung [Maturity model CSR - a definition and demarcation]. In: Schneider, A.; Schmidpeter, R. (eds.). Corporate Social Responsibility. Verantwortungsvolle Unternehmensführung in Theorie und Praxis [Corporate social responsibility. Responsible corporate management in theory and practice]. Berlin/Heidelberg: Springer Gabler, p. 17-38. ISBN 9783642253997. DOI 10.1007/978-3-642-25399-7_2.

Schneider, A. (2015). Reifegradmodell CSR - eine Begriffsklärung und -abgrenzung [Maturity model CSR - a definition and demarcation]. In: Schneider, A.; Schmidpeter, R. (eds.). Corporate Social Responsibility. Verantwortungsvolle Unternehmensführung in Theorie und Praxis [Corporate social responsibility. Responsible corporate management in theory and practice]. 2nd added and expanded edition. Berlin/Heidelberg: Springer Gabler, 2015, p. 21-42. ISBN 9783662434826. DOI 10.1007/978-3-662-43483-3_2.

Schultz, F. (2011). Moralische und moralisierte Kommunikation im Wandel: Zur Entstehung von Corporate Social Responsibility [Moral and moralized communication in flux: The emergence of corporate social responsibility]. In: Raupp, J.; Jarolimek, S.; Schultz, F. (eds.). Handbuch CSR. Kommunikationswissenschaftliche Grundlagen, disziplinäre Zugänge und methodische Herausforderungen [CSR manual. Communication science basics, disciplinary approaches and methodological challenges]. Wiesbaden: Springer VS, p. 19-44. ISBN 9783531170015. DOI 10.1007/978-3-531-92639-1_2.

Stark, J. (2020). Product Lifecycle Management (Volume 1). 21st Century Paradigm for Product Realisation. 4th edition. Switzerland: Springer International, p 1-33. ISBN 9783319330501.

Stolzenberg, K.; Heberle, K. (2020). Change Management. Veränderungsprozesse erfolgreich gestalten - Mitarbeiter mobilisieren. Vision, Kommunikation, Beteiligung, Qualifizierung [Change management. Design change processes successfully - mobilize employees. Vision, communication, participation, qualification]. ISBN 9783662618943.

Stüttgen, M. (2017): Ethisch investieren. Chancen und Grenzen moralisch begründeter Geldanlage [Invest ethically. Chances and Limits of Morally Justified Investments]. Volume 17, published by G. Droesser and R. Hutzel, 2nd reworked edition. 


\section{ENTREPRENEURSHIP AND SUSTAINABILITY ISSUES}

ISSN 2345-0282 (online) http://jssidoi.org/jesi/

2021 Volume 8 Number 4 (June)

http://doi.org/10.9770/jesi.2021.8.4(19)

Thommen, J.-P.; Achleitner, A.-K.; Gilbert, D. U.; Hachmeister, D.; Jarchow, S.; Kaiser, G. (2020). Allgemeine Betriebswirtschaftslehre: Umfassende Einführung aus managementorientierter Sicht [General Business Administration: Comprehensive introduction from a management-oriented point of view]. $9^{\text {th }}$ edition. Wiesbaden: Springer Gabler. ISBN 9783658272463.

Thompson, L.; Hiltrud, W. in interview with Hage, S.; Hesse, M. and Hülsen, I., Der Spiegel, 2019(13), p. 68-69.

Treviño, L. K.; Brown, M. E. (2004). Managing to be ethical: debunking fife business ethics myths. Academy of Management Executive, 18(2), p. 69-81. DOI 10.5465/ame.2004.13837400.

VISSER, W. (2011). The Age of Responsibility: CSR 2.0 and the New DNA of Business. UK: John Wiley \& Sons. ISBN 9780470688571.

VW Group (2018). Shift, Braunschweig: Self-published.

VW Group (2018). Shift. Braunschweig: Self-published.

VW Group (2018). Sustainability Report 2017: Empowering Transformation, Braunschweig: Self-published.

VW Group (2018). Sustainability Report 2017: Empowering Transformation. Braunschweig: Self-published.

VW Group (2020). Whistleblower System, retrieved 18.03.2021, from https://www.volkswagenag.com/en/group/compliance-and-riskmanagement/whistleblowersystem.html

VW GROUP. Hinweisgebersystem [Wistleblower System]. Retrieved 18.03.2021, from https://www.volkswagenkonzernlogistik.de/de/meta/whistleblowersystem.html

Wahyudi, S. M.; Chairunesia, W.; Molina; Indriyanto, E. (2020): The effect of good corporate governance mechanism, corporate social responsibility, and opportunity set investment on corporate value (Empirical Study on Property and Real Estate Companies listed on the Indonesia Stock Exchange in 2014-2017), EPRA International Journal of Multidisciplinary Research (IJMR), 6(1), p. 56-63.

Weaver, G. R.; Treviño, L. K.; Agle, B. (2005). Somebody I Look up to: Ethical Role Models in Organizations. Organizational Dynamics, 34(4), p. 313-330. DOI 10.1016/j.orgdyn.2005.08.001.

Webers, T. (2020). Systemisches Coaching [Systemic coaching]. 2nd edition. Berlin/Heidelberg: Springer. ISBN 9783662613351.

Worbach, M.; Drechsel, B.; Carstensen, C. H. (2019). Messen und Bewerten von Lernergebnissen [Measure and evaluate learning outcomes]. In: Urhahne, D.; Dresel, M.; Fischer, F. Psychologie für den Lehrberuf [Psychology for the teaching profession]. Berlin, Heidelberg: Springer, p. 493-516, ISBN 9783662557532. DOI 10.1007/978-3-662-55754-9_25.

Juliane MEIXNER, PhD. Student, Comenius University Bratislava, Faculty of Management, Slovakia.

ORCID ID: orcid.org/0000-0003-4754-6134

Prof. Ing. Jozef PAPULA, PhD. Professor Comenius University Bratislava, Faculty of Management, Slovakia.

ORCID ID: orcid.org/0000-0001-5861-5567

Make your research more visible, join the Twitter account of ENTREPRENEURSHIP AND SUSTAINABILITY ISSUES: @Entrepr69728810

Copyright (C) 2021 by author(s) and VsI Entrepreneurship and Sustainability Center

This work is licensed under the Creative Commons Attribution International License (CC BY).

http://creativecommons.org/licenses/by/4.0/

(c) (i) Open Access 